Csák László:

\title{
Európai integráció - európai kérdések
}

\author{
1998. Szeged
}

\author{
"Ön Európát rabolja éppen. - búgja az asszony. \\ Ugyan már, kedvesem, mit nem mond! - kacsint az úr. \\ Hát hol van itt Európa? \\ Nézzen szét! Nézzen magába!"
}

(Cseh Tamás: Tangó)

\section{Bevezetés}

1998. szep+ ’mberében a József Attila Tudományegyetem Filozófia Tanszékének szervezésében Európai integráció - európai filozófia címmel konferenciát tartottak Szegeden. Az itt következő rövid írásban megkísérlem összegezni mindazon megfontolások eredményeit, melyek az ott elhangzott referátumok és előadások alapján körvonalazódtak bennem.

Magam részéról nem kívánok minden egyes felszólalást tüzetesebben megvizsgálni, hiszen az sokkal kimerítóbb tárgyalást kívánna meg. Inkább az alábbi módszert követtem. Végighallgattam valamennyi előadást, referátumot, és a kapcsolódó hozzászólásokat is. Eközben a fontosabbnak ítélt gondolatokat lejegyeztem; majd végül három fö címszó alá csoportosítva dolgoztam fel óket.

Az itt következő írás szerkezete is ezt a csoportosítást követi. Először az integráció legitimációs lehetôségeit veszem szemügyre; majd a nemzeti identitás és az európaiság kérdéskörét; végül pedig az integráció és a differenciálódás ügyében fogalmazódnak meg bizonyos kérdések.

\section{Hagyomány és jövôkép}

Alapvetô minden emberi cselekedettel kapcsolatban, legyen szó akár egyéni, akár társadalmi szintű lépésról, a miért kérdésére adandó válasz, a szükségesség megalapozása. S mivel ezen mozgások általá- nosan az idóben (történelmi vagy személyes idó) játszódnak le, ennek természetéból, valamint a folyamatosság emberi igényéból fakadóan két irányú lehet ezen legitimáció. Egyrészt eredeztethető a múltból, azaz a hagyományok felól. Másrészt pedig arra irányul, mit kívánunk elérni, miféle felsóbb jót céloznak cselekedeteink, milyen állapotot tartanánk kívánatosnak. Európa felé törekvésünket tehát egyrészt a hagyomány, másrészt az elérendő célok felól szükséges legitimálnunk. Olymódon, hogy a hagyomány és a jövókép közti folyamatosságot megteremtő összekötő kapocs mi magunk legyünk.

De egyáltalán, miféle Európáról beszélhetünk? Földrajzi, politikai, netán kulturális Európáról? Az első értelemben máris problémákkal találkozhatunk. Ámbár természettudományos kérdésról lévén szó, adhatunk egyféle definíciót, mely az ázsiai kontinens (vagy ha úgy tetszik: Eurázsia) Uráltól nyugatra fekvő területét nevezi eképpen.

A politikai értelemben vett határvonal már sokkal bonyolultabb kérdésnek tünik. A történelmet tekintve nem is nagyon van értelme ilyesmiról beszélni. Hiszen az Okcidens mindig is élesen elkülönült e területegység ôt néha évszázadokkal lemaradva követő fél- vagy egész-perifériáitól. A mai értelemben vett politikai Európa tehát hagyományosan az Okcidensnek felel meg területileg. S így vajon milyen kapcsolat- 
ban állhatunk mi a politikai hagyományt tekintve a mindig is követni kívánt, ám igazán soha be nem ért Európával?

A kulturális értelemben vett Európa határait talán lehetetlen is meghúzni. Tarson mondjuk a Lajtáig, vagy érjen egészen az utolsó, még a Monarchia idején épült galliciai vasútállomásig? Fedje le a nyugatikesztény államokat? Beletartozhat-e a Balkán? S ha szúkebb területre korlátozzuk, kizárható-e belóle Közép-Európa népeinek kultúrája, vagy éppen Tolsztoj? Annyi mindenestre belátható, hogy Európa kulturális határai nem adhatóak meg földrajzi vagy politikai meghatározásokkal.

Miról szól azonban az európai eszmeiség, amit mint közös hagyományt kellene felmutatnunk ahhoz, hogy legitimációs alapként hivatkozhassunk rá. Címszavakban: polgárosodásról, humanizmusról, demokráciáról és szabadságról.

Amennyiben létezik nemzeti karakter, értékrendszer, s hagyomány hazánkban, vajon mutat-e rokonságot a fönti eszmékkel? A polgári gondolatkör és a humanizmus talán jellemezte a magyar társadalom kulturális elitjének bizonyos részeit némely korokban. Gondoljunk csak a Kiegyezéstól az I. világháborúig a Monarchia keretein belül kialakult igen jelentős teljesítményekre, a színházakra, a palotákra, a folyóiratokra és a lapok sokaságára. Ám hogy ezen két eszme, különös tekintettel a polgárságra, valaha is komoly szerepet játszott volna Magyarországon, erősen kétséges. Hiszen az említett bő harminc évet leszámítva ebból a szempontból valóban siralmas képet nyújt történelmünk. Még e rövid időszakban is csupán elszigetelten, Pest-Budára és néhány jelentősebb városra korlátozódott a fejlődés; s az országra a tudatlanság, az elmaradottság, a fél-feudális állapot volt jellemzó.

Hogyan áll a helyzet a demokráciával és a szabadsággal? Szabadelvú irányzatok megléte, már a XIX. században, tagadhatatlan; de hogy a szabadság eszméje össztársadalmi szinten megvalósult volna, erösen vitatható. Demokráciáról az 1945-tól 1948-ig tartó időszakban beszélhetünk. Tényszerüen négy évnyi demokráciát mutathatunk fel; természetesen nem elvitatva egyes személyek, elszigetelt csoportok demokratikus beállítódottságát. Ám ahhoz, hogy valamit magyar hagyományként mutathassunk föl, ennél jóval többre volna szükség.

És egyáltalán, ha ma az egységesülő $\mathrm{Eu}$ rópára tekintünk, vajon ezen értékek mentén rendeződik-e az ottani világ? Arról, hogy mit jelent a Világháború utáni Európának a szabadság és a demokrácia, csak két évszámot és két tulajdonnevet említenék: 1956., 1968., Bosznia, Koszovó.

Lehetséges tehát, hogy amikor hazánk kulturális és politikai elitjével az élen Európa felé igyekszik, $\mathrm{s}$ ezt valamiféle feltétlen áramlásnak, történelmi szükségszerüségnek fogja föl, bizonyos pontokon téved. A legitimációt ugyanis a közös hagyomány, a közös eszmék, valamint a gazdasági célok alapján szokás megalapozni. Láttuk azonban, hogy az európai hagyomány nem feltétlen közös; továbbá hiába rendelkezik európai eszmeiséggel hazánk értelmiségének jelentős része, ha mindez nyugaton már egészen más jelentéssel bír. Végül pedig, ami a feltétlen áramlást illeti, ez bizonyosan ellentétes a polgáriság fontos jegyeivel. Ezt ugyanis az önálló véleményalkotás, valamint ezen elképzelések megvalósíthatóságába vetett hit jellemzi. S az így felfogott polgár nem arról ismerszik meg, hogy feltétlenül igenli csatlakozásunkat, sokkal inkább arról, hogy saját megfontolásokra alapozott véleménnyel rendelkezik ezügyben.

Végül nézzük meg, mi a helyzet a jövőképpel! Milyen célok elérése érdekében jött létre az Unió? Legfóképpen gazdasági érdekek alapján, gondoljunk csak a Vas és Szén Unióval fémjelzett kezdetekre. Másodsorban a Szovjetunió ellensúlyozására, harmadsorban pedig egy lehetséges háború elkerülése érdekében. Így látszott ugyanis feloldhatónak a német-francia szembenállásból adódó feszültség.

Az, hogy az utóbbi kettő mára okafo- 
gyottá vált, minket vajmi kevéssé érint; hagyjuk meg ezen probléma boncolgatását az Uniónak. Ám mi marad így egyedül? Az Unió jelenlegi gazdasági és hatalmi szerepének fenntartása. Egy szó nem esik itt szellemról, kultúráról, múveltségról; csak pénzról és hatalomról. S kellhet-e e kettőnél jobb legitimációs forrás?

\section{Nemzeti identitás és európaiság}

Amennyiben sikerülne legitimálni a hagyomány és a célok szempontjából csatlakozásunkat, mit jelenthetne ez az egyes állampolgárok személyes életében, önképükre nézve, mennyiben kapna új tartalmat az egyén, és a nemzet mint egyének összességének identitása?

Adott szen. śly önmeghatározása egyrészt belső világáról, szellemi képességeiról, teljesítményéról szól. Másrészt azonban, és itt most erre kívánom fektetni a hangsúlyt, a közösség felóli öndefiniálást jelenti. A sokféle közösség közül tekintsük a nemzetet, mint közösséget.

Nemzeti identitásunk általánosan két tényezót tartalmaz: a politikai és a kulturális értelemben vett nemzettudatot; amennyiben valaki rendelkezik nemzeti identitással. Magyarországon jelenleg még nem dólt el, melyik is kerül majdan túlsúlyba. Ám az, hogy független fejlődés melyik válna meghatározóvá, kikutathatatlan, hiszen az uniós csatlakozás identitásformáló hatásától már ma sem tekinthetünk el.

Mindenesetre a nyugat-európai államokban a meghatározó nemzeti identitás mára már politikaivá vált, sőt erôteljesen megjelent a kozmopolita önmeghatározás, és egyúttal a kulturális nemzeten alapuló háttérbe szorult. Az Unió, mivel belső fejlödése, a határok felszámolódása, a teljes egységesülés még folyamatban van, maga is folyamatosan változik. Milyen lehet a késóbbi európai identitás amennyiben feltételezzük, hogy létrejön valamiféle európa-polgár önmeghatározás?

Azt gondolom, politikai értelemben talán létrejöhet tekintve, hogy ez eleve gyen- gébb összekötő kapocs, mint a nemzetire alapozott; másrészt a nyugat-európai államokban a polgári demokrácia intézménye mindenütt szilárd, s néhány kivételtól eltekintve, hosszú hagyománnyal rendelkezik. Ebbe a rendszerbe Magyarország is könynyen betagozódhat, hiszen jogrendünk és intézményrendszerünk egyre inkább megközelíti az uniós elvárásokat.

Természetesen valamiféle kulturális identitásbeli egységesülés is bekövetkezhet. Egyrészt a multikulturalitás okán, ez azonban nem valamiféle önálló európai gondolat, inkább csak afféle coca-cola érzés. Nagyobb jelentőséggel a mi szempontunkból inkább a jelentősebb nemzeti kultúrák versenye, és a kisebbek ezekben való feloldódása bír. Kizárt, legalábbis rövid távon, hogy összeegyeztethetővé váljon az angolszász, a német, a francia, vagy épp a spanyol kultúra. Igaz, az angolszász hegemónia megjelenését jelzi például a francia nyelvtörvény, amit éppen ez tett szükségessé. Bár ez inkább a már említett multikulturalitásnak tudható be, semmint a brit hatásnak.

Kulturálisan tehát még semmi sem dólt el, s talán a multikulturalitás mintegy fö-

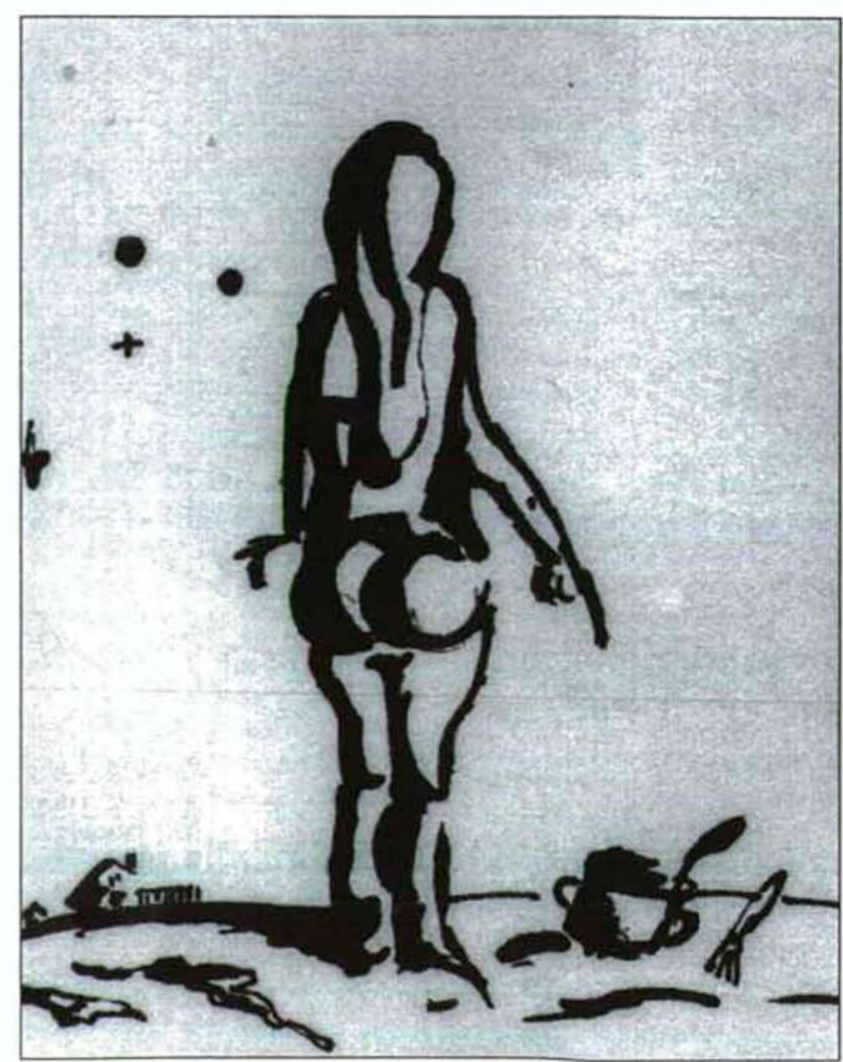


lülírja majd valamennyi eddigi megfontolásunkat. Azt azonban megjegyezhetjük, hogy az európai kultúra összetettsége, az egyes nemzeti kultúrák a szellemi sokféleség és sokrétúség elvesztése mindenképp hátrányt jelentene.

A kulturális betagozódás megvalósulására két, hazánkra közelítóleg alkalmazható példát szokás megemlíteni. Az egyik a spanyol, a másik pedig a finn tapasztalatokat érinti. Spanyolországban a nemzeti értékek megérzésére, önálló karakter kialakítására törekedtek az Unión belül. A finn filozófia ellenben gyakorlatilag beleolvadt az angolszász vonalba.

Ám akármelyiket választjuk is, igen nagy problémákkal találjuk magunkat szembe. Hiszen irodalmunk, múvészetünk valóban értékes megnyilvánulásai a maguk korában legalábbis idegenszívúséggel vádoltattak meg; gondoljunk csak Adyra vagy Radnótira. S be kell vallanunk, valóban ezer szállal kötődnek ók Párizshoz, Európához, $\mathrm{s}$ jóval kevésbé a díszmagyarhoz, a párbajkódexhez, a vitézi hagyományokhoz. Ha a jelenre figyelünk, akkor is nehéz eldönteni, melyik hagyományt követő Magyarországot nevezhetnénk nemzeti karakterünek.

$\mathrm{Ha}$ azonban finn mintára, valamely meghatározó kultúrkörben kívánnánk feloldódni, vajon melyik is legyen az. Kulturális elitünk, amióta ilyesmiról beszélhetünk, igen megosztott volt, sokféle kötődéssel. És akkor ezen elitek közül melyiket válasszuk? Hiszen adódik rögtön német, francia, némi angolszász, s talán még ausztro-katolikus is. (Amennyiben önálló alakulatként egyáltalán meghatározható ez utóbbi.)

S ha már ily sok kérdőjelre leltünk saját leendő európai identitásunkkal kapcsolatban, fölmerül a kérdés, hogy vajon helyese, megtehető-e, megéri-e feladni kétségkívül meglévő kulturális nemzeti identitásunkat az integrációból fakadó nem-istudjuk-miért.

\section{Integráció és differenciálódás}

Végül vizsgáljuk meg, hogyan is áll a helyzet az integráció eszméjének szükségességével, melyet oly sokan oly sokszor hangoztatnak. Ha figyelmesen olvassuk napilapjainkat, kulturális és társadalomtudományi folyóiratainkat, hallgatjuk politikusaink és értelmiségünk meghatározó tagjainak megnyilatkozásait, az a benyomásunk támadhat, mintha az integráció valamiféle abszolút és feltétlen jó volna, minden boldogság és öröm egyetlen forrása. Sőt, nem csupán a mi korunkban van ez így, de ilyen szerepet töltött be már a történelemben is. Anélkül, hogy elvitatnánk a csatlakozástól lehetséges pozitív következményeit, vizsgáljuk meg, valóban egyedül üdvözítő útja-e az európai fejlődésnek, ami a múltat, a történelmet illeti.

Kétségtelen, hogy a német egység létrejötte igen kedvezóen hatott annak idején a germánság európai helyzetének megerősödésére. A széthúzó és független fejedelemségekból kialakult egységes állam, jóval erôsebbnek bizonyult gazdasági, politikai, és természetesen katonai szempontból is, szellemi eredményeikról nem is beszélve.

Egységes, több tartomány egyesülésével létrejött állam volt azonban Spanyolország is, amikor Németalföld szabadságmozgalmait igyekezett megtörni, s a saját képére formálva beilleszteni azt államtestébe. ez azonban, miként azt a történelemból jól tudjuk, nem járt sikerrel. Hosszas és kiterjedt próbálkozásaik ellenére még a spanyol mintájú adórendszert sem voltak képesek megteremteni.

Ebból a példából is látható, hogy a differenciált, nem egységesített államszervezet nem jelent valamiféle feltétlen negatívumot. Sốt, ha a németalföldi kereskedelem, gazdaság, és szellem akkori teljesítményét tekintjük, akkor sem találunk érveket, amelyek esetleg széttagoltsága ellen szólnának, ellenkezóleg. Az tehát, hogy az integráció, vagy a differenciálódás jelent pozitívumot, sokkal inkább attól függ, miféle tartalommal sikerül megtölteni.

De tekintsünk egy hozzánk sok szem- 
pontból közelebb álló példát, nevezetesen az Osztrák-Magyar Monarchiát. Azt gondolom, hogy ezen meddő, fejlődésképtelen államalakulat nemzetállamokra való felbomlása tartalmaz bizonyos pozitívumokat. Ausztria, de különösen Csehország számára járt ez óriási elönyökkel. Gondoljunk csak a nemzeti önállóságból fakadó kulturális felvirágzásra, a masaryki korszak demokratizmusára, és polgárosodására.

De vajon jelenleg is csupán az integráció volna jellemző, vagy pedig léteznek bizonyos differenciálódást célzó törekvések, mozzanatok is? Elég, ha csak a szeparatizmus máig élő formáira, vagy egyes kis népek kultúrájának, sőt nyelvének újjáéledésére gondolun.. Vagy éppenséggel hivatkozhatnánk a régiók Európájára is, hogy a differenciálódást jelző mozzanatok közül a legjelentősebbet is megemlítsük.

Kiemelhető valami tisztán kulturális vonás is. Nyilvánvaló, hogy a távolságok és a határok megszúnésével a kultúrák közti érintkezés is erősödik. S így erőteljesebbé válik azok egymásra hatása, kisebb kultúrák létrejötte, egymásba való feloldódása. Érdekes megjegyeznünk, hogy mindennek éppen az integráció nyit teret.

Látjuk tehát, hogy az integráción kívül annak ellentétére, a differenciálódás pozitív hatására is lelhetünk példákat, mind az európai történelem távolabbi és közelebbi fejezeteiben, mind pedig a jelenkorban. Úgy tûnhet, mintha az európai szellemiség egy nagy-nagy kosár volna, amiben benne van minden eszme, s mellette mindnek teljes ellentéte is, s ki-ki kiválogathatja a magának tetsző gondolatokat.

Azonban megtehető-e, vagy inkább: elfogadható-e, hogy az ellentétes eszméket magukhoz vevók mind ugyanarra a kosárra hivatkoznak? Vagy inkább azt kellene mondanunk, hogy evvel nem alapozták meg elképzelésüket, csupán megjelölték, honnan származtatják.

Mert bizony, abban a kosárban benne van nem csak az integráció és ellentéte, azaz a differenciálódás; hanem a humaniz- mus eszméje és a vele szemben álló ordas eszmék; ugyanúgy megtaláljuk benne a béke, mint a háború eszméjét. Európa egymásnak ellentmondó eszmék foglalata volna? De akkor mit jelent az, ha valaki rá hivatkozva próbálja gondolatait megalapozni? Mit jelent egyáltalán, ha azt mondom: európai vagyok?

\section{Konklúzió?}

$\mathrm{Az}$ eddigiekben tehát megfogadván a mottóban szereplő felszólítást, szétnéztünk Európa történelmében, kultúrtörténetében és jelenében, s egyúttal saját identitásunkra, integrációs törekvéseinkre rákérdezve magunkba is néztünk.

S hogy mit találtunk? Röviden összegezve: csupa kérdőjelet, bizonytalanságot. Láthattuk, hogy a legitimáció szempontjából igen problematikus a dolog, akár a hagyomány, akár a célkitûzés kerül vizsgálatra. $\mathrm{Az}$ identitással kapcsolatos felvetés sem szolgáltatott fogódzókat a még létre sem jött európa-polgár identitásra nézve. Nem tudjuk, milyen út volna követhető számunkra. Hasonlóan jártunk az integráció abszolút voltát, valamint a differenciálódás európai szerepét illetően is.

Miben lelhetünk mégis bizonyosságot? Társadalmi, kulturális, közösségi szinten bizonytalanságra leltünk. Talán az egyén, azaz saját magunk szempontjából mégis juthatunk valamiféle eredményre.

Amikor népszavazást tartottak hazánk leendő NATO csatlakozásáról, hasonló kérdésekkel küszködhettünk. Máig sem vagyok bizonyos benne, valóban szeretném-e, ha újra idegen csapatok állomásoznának Magyarországon. Akkori döntésemre egyetlen indokot találtam. Egyértelmú ugyanis a választási kényszer kelet és nyugat között; és én nem akarom, hogy bármikor elvihessenek; nem akarok félretenni egy összeget, amiból, ha valami történik itt, a Lajtán túlra juthatok. Vagy ahogy Vajda Mihály fogalmazott a szegedi konferencián, ha nem megyünk az unióba, akkor az ukrán maffia marad.

A nyugat választása csupán a kelet tagadása volna? 